\title{
Alkalinasi dan Fermentasi Jerami Jagung untuk Penurunan NDF, ADF dan Selulose sebagai Pakan Dasar Ruminansia
}

\section{(Alkalination Fermentation of Corn Straw for Decreasing of NDF, ADF and Cellulose as Basic Feed for Ruminant)}

\author{
Ali U, Iswanto T \\ Fakultas Peternakan, Universitas Islam Malang, Jl, Mayjen Hariono no.193, Dinoyo Malang 65144 \\ usmanchalim@gmail.com
}

\begin{abstract}
The Abundant corn straw waste can support the availability of basic ruminant feed, but the quality and nutritional content are low with crude fiber component above $25 \%$, therefore organic waste needs to be treated by alkalination and fermentation. The study aimed to evaluate the content of Neutral Detergent Fiber (NDF), Acid Detergent fiber (ADF), hemicellose and cellulose in corn straw give alkalination treatment of lime and Aspergillus niger fermentation. The research material was $15 \mathrm{~kg}$ of chopped straw, quicklime and Aspergillus niger. The experimental research method using a completely randomized factorial design $3 \times 3$, repeated 3 times. The first factor was the addition of lime $\mathrm{Ca}(\mathrm{OH})_{2} 4 \%, 5 \%$, and $6 \%$ of dried corn straw, factor II fermentation using Aspergillus niger $\left(1.02 \times 10^{8} \mathrm{CFU} / \mathrm{ml}\right)$ in doses $3 \mathrm{ml}, 4 \mathrm{ml}$, and $5 \mathrm{ml} / 500 \mathrm{~g}$ for 5 days with humidity $40 \%$ and control samples. Variable data were analyzed by two-way nt variance (ANOVA, if there was a real effect followed by the Smallest Significant Difference Test. The results showed that alkalination of lime, fermentation and its combination was very significant $(\mathrm{P}<0.01)$ reducing the content NDF, ADF, hemicellulose and cellulose corn straw. The average content of NDF, ADF and cellulose in sequential treatments ranged (47.58\%-65.14\%); (43.39\%-55.33\%) and $(36.99 \%$ $46.28 \%$ ). While the average content of NDF, ADF and Cellulose in the control sample without treatment was $70.37 \% ; 59.29 \%$; and $50.63 \%$. It was concluded that the best treatment are combination of alkalination $5 \%$ lime and fermented $5 \mathrm{ml} / 500 \mathrm{~g}$ with content $\mathrm{NDF} 47.58 \%$; ADF $43.39 \%$ and cellulose $36.99 \%$.
\end{abstract}

Key words: Corn straw, alkalination, fermentate, component crude fiber

\begin{abstract}
ABSTRAK
Limbah jerami jagung melimpah dapat mendukung ketersediaan pakan dasar ruminansia, namun kualitas dan nutrisnyai rendah dengan komponen serat kasar di atas 50\%, maka perlu diolah dengan alkalinasi dan fermentasi. Penelitian ini bertujuan untuk mengevaluasi kandungan Neutral Detergent Fiber (NDF), Acid Detergent fiber (ADF), hemiseluosa dan selulosa dalam jerami jagung yang diberi perlakuan alkalinasi kapur dan fermentasi Aspergillus niger. Materi penelitian jerami jagung tercacah sebanyak $15 \mathrm{~kg}$, kapur tohor dan kapang Aspergillus niger. Metode penelitian menggunakan Rancangan Acak Lengkap (RAL) faktorial ortogonal $3 \times 3$, diulang 3 kali. Faktor I penambahan kapur $\mathrm{Ca}(\mathrm{OH})_{2}$ 4, 5 dan $6 \%$ dari jerami jagung kering, faktor II fermentasi menggunakan kapang Aspergillus niger $(1,02 \mathrm{x}$ $10^{8} \mathrm{CFU} / \mathrm{ml}$ ) dengan dosis 3, 4, dan $5 \mathrm{ml} / 500 \mathrm{~g}$ bahan selama 5 hari dengan kelembaban $40 \%$ dan sampel kontrol. Data variabel dianalisis ragam (ANOVA) dua arah, jika ada pengaruh nyata dilanjutkan Uji Beda Nyata Terkecil (BNT). Hasil penelitian menunjukkan bahwa alkalinasi kapur, fermentasi dan kombinasinya sangat nyata $(\mathrm{P}<0,01)$ menurunkan kandungan NDF, ADF, hemiselulose dan selulosa jerami jagung. Rataan kandungan NDF, ADF dan
\end{abstract}


selulosa pada perlakuan berurutan berkisar (47,58 - 65,14\%); (43,39 - 55,33\%) dan (36,99 46,28\%). Sedangkan rataan kandungan NDF, ADF dan Selulosa pada sampel kontrol tanpa perlakuan sebesar 70,37; 59,29; dan 50,63\%. Kesimpulan perlakuan terbaik pada kombinasi dosis alkalinasi kapur 5\% dan fermentasi $5 \mathrm{ml}$ Aspergillus niger/500 g bahan dengan kandungan NDF 47,58\%; ADF 43,39\% dan selulosa 36,99\%.

Kata kunci: Jerami jagung, alkalinasi, fermentasi, komponen serat kasar

\section{PENDAHULUAN}

Tanaman jagung selain menghasilkan buah atau biji yang dimanfaatkan sebagai bahan pangan, jagung juga menghasilkan limbah berupa batang, daun, tongkol dan kulit buah atau bijinya yang dapat dimanfaatkan sebagai pakan ternak ruminansia (Anonimous 2007). Limbah jagung yang paling banyak adalah bagian batang dengan nutrisi dan tingkat kecernaan yang rendah serta serat kasar di atas $25 \%$. Komponen serat kasar atau dinding sel tanaman berupa Neutral Detergent Fiber (NDF). NDF terbagi menjadi hemiselulosa dan Acid Detergent Fiber (ADF). ADF tersusun dari selulose, lignin dan silika. Salah satu solusi untuk meningkatkan kecernaan limbah jerami jagung adalah dengan cara melakukan alkalinasi dan fermentasi. Dengan melakukan proses tersebut diharapkan dapat menambah nilai nutrisi dalam jerami jagung, sehingga kebutuhan gizi pada ternak dapat terpenuhi.

Alkalinasi sebagai proses pemisahan substansi campurannya menggunakan larutan alkali. Pada prinsipnya kerja alkali terhadap bahan berserat adalah memutuskan sebagian ikatan antara selulosa dan hemiselulosa. Kalsium hidroksida $\mathrm{Ca}(\mathrm{OH})_{2}$ dapat digunakan sebagai bahan proses perenggangan lignoselulosa karena banyak terdapat di alam, tidak berbahaya dan dapat menambah nilai nutrien, yaitu mineral kalsium. Penggunaan $\mathrm{Ca}(\mathrm{OH})_{2}$ juga tidak memberikan dampak negatif pada lingkungan (Firdos et al. 1989; Fadel et al. 2003). Aspergillus niger merupakan mikroba selulolitik karena dapat menghasilkan enzim selulase untuk memecah senyawa selulosa menjadi glukosa, sehingga mudah dicerna oleh ternak (Niken 2009). Selain itu, Aspergillus niger mudah tumbuh dengan cepat dan juga merupakan salah satu spesies Aspergillus yang tidak menghasilkan mikotoksin, sehingga tidak membahayakan. Fermentasi dapat meningkatkan nilai gizi pakan yang rendah dan sebagai metode pengawetan bahan pakan. Shabi (1998) menyatakan bahwa aktivitas mikroba akan optimal dalam memanfaatkan nitrogen pakan jika tersedia energi yang cukup dan sesuai fermentabilitasnya. Metabolisme mikroba rumen di atur oleh jumlah dan kecepatan degradasi karbohidrat dan protein. Kondisi ini sangat dipengaruhi oleh karakteristik fisik dan kimia pakan (Maeng 1997). Pengolahan limbah jagung sangat diperlukan agar kontinuitas pakan terus terjamin. Masyarakat sebagian besar memberikan limbah tersebut kepada ternak secara langsung setelah jagung dipanen, namun tak banyak masyarakat memproses limbah tersebut sebagai pakan cadangan. Berdasarkan uraian tersebut maka perlu dilakukan penelitian untuk mengetahui pengaruh alkalinasi dan fermentasi jerami jagung terhadap kandungan NDF, ADF dan Selulosa.

\section{MATERI DAN METODE}

Materi yang digunakan dalam penelitian ini adalah kalsium kidroksida $\mathrm{Ca}(\mathrm{OH})_{2} \%$ b/b, polybag, air bersih dan ember untuk pencampuran bahan. Kapang Aspergillus niger $1,02 \times 10^{8} \mathrm{TPC} / \mathrm{ml}$, jerami jagung setelah panen berumur 90 hari. Metode penelitian menggunakan Rancangan Acak Lengkap (RAL) pola faktorial ortogonal 3 x 3 yang 
diulang 3 kali. Perlakuan disusun sebagai berikut: perlakuan pertama Alkainasi (A) dengan dosis $4 \%$ b/b (A1), dosis $5 \%$ b/b (A2) dan dosis $5 \%$ b/b (A3); perlakuan kedua fermentasi dengan Aspergillus niger dosis $3 \mathrm{ml} / 500 \mathrm{~g}$ bahan (F1), dosis $5 \mathrm{ml} / 500 \mathrm{~g}$ bahan (F2) dan dosis $6 \mathrm{ml} / 500 \mathrm{~g}$ bahan (F3), perlakuan kontrol serta perlakuan kombinasi alkalinasi dan fermentasi (AF), yaitu A1F3 (kapur 4\% + Aspergillus niger $3 \mathrm{ml}$ ), A1F4 (kapur 4\% + Aspergillus niger $4 \mathrm{ml}$ ), A1F5 (kapur 4\% + Aspergillus niger $5 \mathrm{ml}$ ), A2F3 (kapur 5\% + Aspergillus niger $3 \mathrm{ml}$ ), A2F4 (kapur 5\% + Aspergillus niger $4 \mathrm{ml}$ ), A2F5 (kapur 5\% + Aspergillus niger $5 \mathrm{ml}$ ), A3F3 (kapur 6\% + Aspergillus niger $3 \mathrm{ml}$ ), A3F4 (kapur 6\% + Aspergillus niger $4 \mathrm{ml}$ ), A3F5 (kapur 6\% + Aspergillus niger $5 \mathrm{ml}$ ). Variabel yang diamati adalah kandungan NDF (Neutral Detergent Fiber), ADF (Acid Detergent Fiber) dan Selulosa dalam jerami jagung yang diberi perlakuan alkalinasi dan fermentasi serta kombinasi keduanya dan sampel kontrol tanpa perlakuan. Pada perlakuan yang signifikan akan dilanjutkan Uji Beda Nyata Terkecil (BNT) untuk mengetahui antar perlakuan.

\section{HASIL DAN PEMBAHASAN}

\section{Kandungan Neutral Detergent Fiber (NDF)}

Perlakuan alkalinasi berpengaruh sangat nyata $(\mathrm{P}<0,01)$ terhadap kandungan NDF, hal ini disebabkan saat inkubasi, terjadi peningkatan suhu menghasilkan panas hasil reaksi kapur $\mathrm{Ca}(\mathrm{OH})_{2}$ yang dapat menurunkan nilai kandungan NDF. Rataan tiap perlakuan alkalinasi adalah $\mathrm{A} 4=63,03 \%^{\mathrm{b}}, \mathrm{A} 5=50,21 \%^{\mathrm{a}}$ dan $\mathrm{A} 6=53,75 \%^{\mathrm{a}}$. Perbedaan penambahan kapur menyebabkan perbedaan penurunan kandungan NDF. Penambahan $5 \%$ kapur $\mathrm{Ca}(\mathrm{OH})_{2}$ dapat mendegradasi lignoselulosa lebih maksimal. Selama inkubasi air kapur $\mathrm{Ca}(\mathrm{OH})_{2}$ dapat merenggangkan kandungan NDF. Menurut Pina et al. (2009) perenggangan kandungan NDF dapat disebabkan karena adanya penurunan karbohidrat non struktural selama pemeraman berlangsung.

Perlakuan fermentasi berpengaruh sangat nyata $(\mathrm{P}<0,01)$ terhadap kandungan NDF. Hal ini disebabkan kapang Aspergillus niger dapat memproduksi enzim selulase yang dapat merombak fraksi serat kasar. Menurut Banwart (1989) Jamur Aspergillus niger mempunyai kandungan nutrisi yang baik dan sebagai penghasil enzim selulase. Hasil rataan setiap perlakuan fermentasi Aspergillus niger adalah $\mathrm{F} 1=57,17 \%^{\mathrm{b}}, \mathrm{F} 2=56,11 \%^{\mathrm{b}}$ dan $\mathrm{F} 3=53,71 \%^{\mathrm{a}}$. Adanya perbedaan kandungan NDF disebabkan penambahan dosis Aspergillus niger berbeda pada setiap perlakuan. Penambahan Aspergillus niger pada dosis $5 \mathrm{ml}$ nyata mendegradasi lignoselulosa lebih maksimal dibandingkan dengan dosis lainnya. Nilai kandungan NDF mengalami penurunan sekitar 23\%. Menurut Raharjo et al. (2000) fermentasi dengan menggunakan inokulum Aspergillus niger menghasilkan perbaikan kualitas nutrisi pollard gandum dan adanya penurunan komponen serat kasar NDF.

Hasil penelitian menunjukkan adanya perbedaan sangat nyata $(\mathrm{P}<0,01)$ antara kontrol dan perlakuan alkali kapur $\mathrm{Ca}(\mathrm{OH})_{2}$ dan fermentasi Aspergillus niger terhadap kandungan NDF. Pada kontrol nilai kandungan NDF sebesar 59,29\% ${ }^{\mathrm{e}}$, sedangkan pada kombinasi alkali kapur $\mathrm{Ca}(\mathrm{OH})_{2}$ dan fermentasi kandungan NDF terendah pada perlakuan A5F5 sebesar $43,39 \%^{\mathrm{a}}$ dan kandungan NDF tertinggi pada perlakuan A4F3 sebesar $55,33 \%$. 


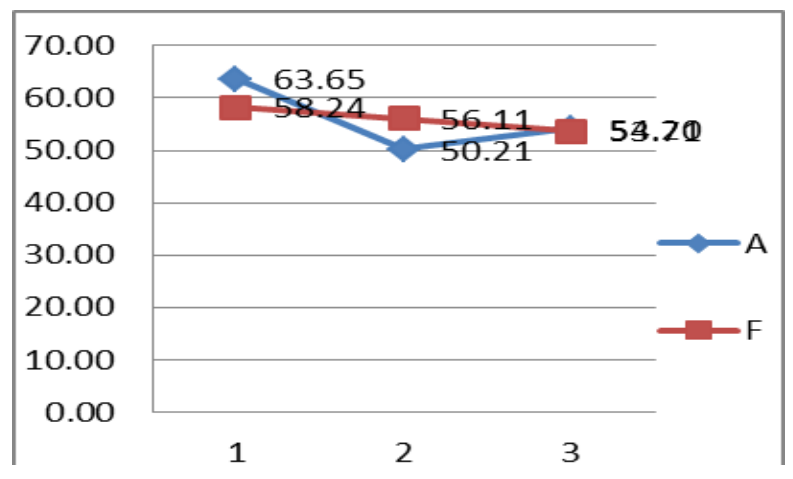

Gambar 1. Pengaruh interaksi alkalinasi dan fermentasi terhadap NDF

Hasil penelitian menunjukkan bahwa interaksi penambahan kapur $\mathrm{Ca}(\mathrm{OH})_{2}$ dan dosis inokulum Aspergillus niger terhadap kandungan NDF berinteraksi positif (Gambar 1). Penurunan kandungan NDF disebabkan kombinasi bahan alkali $\mathrm{Ca}(\mathrm{OH})_{2}$ dan inokulum Aspergillus niger dapat berinteraksi dengan baik dan saling berkesinambungan. Hasil kombinasi yang terbaik adalah kombinasi A5F5. Hal ini disebabkan dalam kondisi $\mathrm{pH}$ yang tidak terlalu tinggi pada proses alkalinasi membuat kapang Aspergillus niger berkembang dengan baik pada proses fermentasi. Menurut Larasati (2015) derajat keasaman $(\mathrm{pH})$ yang mendukung pertumbuhan mikroorganisme adalah $\mathrm{pH}$ dengan sifat asam (rendah) untuk fungi memiliki $\mathrm{pH}$ optimum 5 hingga 8, namun setiap organisme memiliki tingkat toleransi asam yang berbeda dan enzim yang disekresikan keluar akan rusak jika berada pada $\mathrm{pH}$ terlalu asam atau terlalu basa. Proses alkalinasi berfungsi merenggangkan ikatan NDF, sedangakan proses fermentasi berperan memutuskan ikatan lignin sehingga nilai kandungan NDF dapat diturunkan. Menurut Soares (2017) enzim selulase yang dihasilkan dari inokulum Aspergillus niger mampu merombak ikatan-ikatan kompleks dari serat menjadi komponen yang lebih sederhana.

\section{Kandungan Acid Detergent Fiber (ADF)}

Perlakuan alkalinasi berpengaruh sangat nyata $(\mathrm{P}<0,01)$ terhadap kandungan $\mathrm{ADF}$, hal ini disebabkan dalam alkalinasi suhu panas pada inkubasi dapat memecah ikalan lignin sehingga ADF menurun. Hasil rataan masing-masing perlakuan alkalinasi $\mathrm{A} 4=53,38 \%^{\mathrm{b}} \mathrm{A} 5=43,98 \%^{\mathrm{a}}$ dan $\mathrm{A} 6=46,17 \% \%^{\mathrm{a}}$. Adanya perbedaan nilai ADF saat inkubasi pada tiap perlakuan karena adanya perbedaan suhu akan memecah ikatan lignin sehingga terjadi nilai ADF turun. Sedangkan fermentasi berpengaruh sangat nyata $(\mathrm{P}<0,01)$ terhadap kandungan ADF. Hal ini disebabkan oleh kapang Aspergillus niger menghasilkan enzim selulase saat proses fermentasi berlangsung. Menurut Musnandar (2006) penurunan ADF oleh mikroorganisme sejalan dengan produksi enzim dan waktu untuk memasuki jaringan serat. Hasil raataan setiap perlakuan fermentasi Aspergillus niger adalah $\mathrm{F} 3=48,85 \%^{\mathrm{b}}, \mathrm{F} 4=48,04 \%^{\mathrm{b}}$ dan $\mathrm{F} 5=46,64 \%^{\mathrm{a}}$. Penambahan Aspergillus niger pada level $5 \mathrm{ml}$ nyata mendegradasi lignoselulosa lebih maksimal dibanding dengan dosis $3 \mathrm{ml}$, dan $4 \mathrm{ml}$. Hal ini disebabkan adanya perenggangan saat alkalinasi berlangsung. Menurut Soares (2017) kombinasi fermentasi menggunakan Aspergillus Niger dan saccharomyces cereviseae pada ampas putak dapat menurunkan nilai kandungan ADF $14,10 \%$. 
Hasil penelitian menunjukkan adanya perbedaan yang sangat nyata $(\mathrm{P}<0,01)$ antara kontrol dan perlakuan Alkalinasi dan Fermentasi Aspergillus niger. Pada kontrol kandungan $\mathrm{ADF} 59,29 \%^{\mathrm{e}}$, sedangkan pada kombinasi alkali kapur $\mathrm{Ca}(\mathrm{OH})_{2}$ dan fermentasi kandungan ADF terendah pada perlakuan A5F5 sebesar 43,39\% ${ }^{\mathrm{a}}$ dan kandungan ADF tertinggi pada perlakuan A4F3 sebesar 55,33\% .

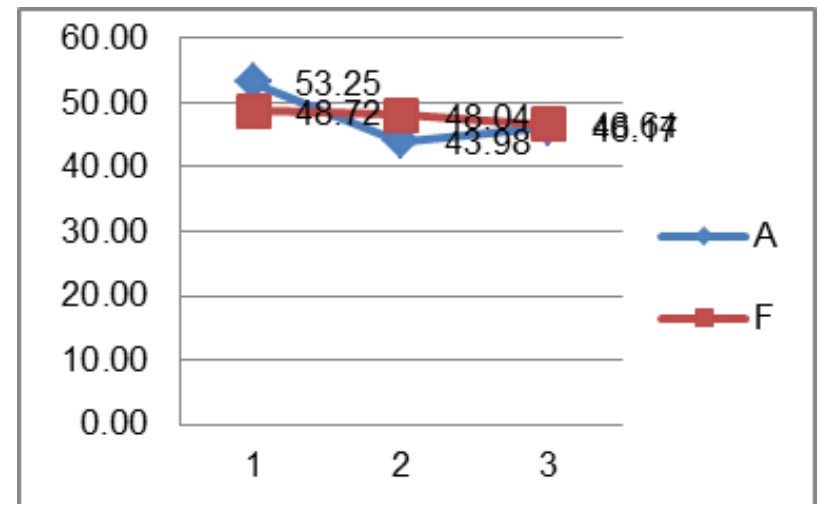

Gambar 2. Interaksi penambahan Kapur dan fermentasi terhadap ADF

Hasil penelitian menunjukkan bahwa intraksi penambahan kapur $\mathrm{Ca}(\mathrm{OH})_{2}$ dan dosis inokulum berpengaruh terhadap kandungan ADF (Gambar 2.). Hal ini sesuai pendapat Murni (2008) alkalinasi dapat memutuskan sebagian ikatan antara selulosa dan hemiselulosa dengan lignin dan merombak struktur dinding sel melalui pengembangan jaringan serat dan memudahkan penetrasi enzim mikroba. Perlakuan A5F5 penggunaan bahan alkali pada perlakuan ini sangat baik dan tidak mempengaruhi fermentasi, sehingga inokulum berkembang dengan baik menghasilkan selulase untuk merombak ikatan lignin, sehingga nilai ADF menurun. Menurut Soares (2017) enzim selulase dari Aspergillus niger mampu merombak ikatan kompleks dari serat menjadi komponen sederhana. Pada perlakuan $\mathrm{A} 4 \mathrm{~F} 3=($ kapur $4 \%+3 \mathrm{ml}$ Aspergillus niger $)$ penggunaan bahan alkali pada perlakuan ini kurang maksimal, karena pada proses alkalinasi $4 \%$ kurang bekerja dengan baik dalam merenggangkan ikatan lignin dan juga pada proses fermentasi inokulum kurang berkembang dengan baik untuk menghasilkan enzim selulase yang berguna untuk memutuskan ikatan lignoselulosa sehingga nilai kandungan ADF menurun.

\section{Kandungan selulosa}

Perlakuan alkalinasi berpengaruh sangat nyata $(\mathrm{P}<0,01)$ terhadap kandungan selulosa, hal ini disebabkan dalam kondisi inkubasi, suhu didalamnya meningkat dan menghasilkan panas hasil reaksi dari kapur $\mathrm{Ca}(\mathrm{OH})_{2}$ yang dapat menurunkan nilai kandungan selulosa. Hasil raataan masing-masing perlakuan alkalinasi adalah $\mathrm{A} 4=44,91 \%^{\mathrm{c}}, \mathrm{A} 5=37,92 \%^{\mathrm{a}}$ dan $\mathrm{A} 6=40,21 \%$. Perbedaan nilai kandungan Selulosa pada tiap perlakuan disebabkan tingkat penambahan kapur $\mathrm{Ca}(\mathrm{OH})_{2}$ yang berbeda. Perbedaan pemberian konsentrasi $\mathrm{Ca}(\mathrm{OH})_{2}$ mempengaruhi produksi jumlah ion hidroksil yang merenggangkan ikatan dari struktur pembentuk lignin, sehingga lignin menjadi lebih mudah untuk dilarutkan (Jalaluddin \& Rizal 2005). Penambahan 5\% kapur $\mathrm{Ca}(\mathrm{OH})_{2}$ dapat mendegradasi lignoselulosa lebih maksimal. Turun dan naiknya nilai kandungan ADF dipengaruhi oleh proses alkalinasi dan fermentasi. Sedangkan fermentasi 
berpengaruh sangat nyata $(\mathrm{P}<0,01)$ terhadap kandungan selulosa. Hal ini disebabkan kapang Aspergillus niger dapat memproduksi selulase yang dapat merombak fraksi SK. Hasil rataan fermentasi Aspergillus niger adalah $\mathrm{F} 3=41,47 \%^{\mathrm{b}}, \mathrm{F} 4=40,84 \%^{\mathrm{a}}$ dan $\mathrm{F} 5=40,73 \%^{\mathrm{a}}$. Adanya perbedaan nilai Selulosa disebabkan pemberian dosis mikroba berbeda. Penambahan Aspergillus niger pada level $5 \mathrm{ml}$ mendegradasi lignoselulosa lebih maksimal dibanding dengan dosis lainnya, disebabkan adanya perenggangan saat proses alkalinasi berlangsung. Menurut Raharjo et al. (2000) Selama proses fermentasi Aspergillus niger mampu memproduksi enzim-enzim katabolik seperti amilase, isoamilase, manase, selulase dan amiloglukosidase sehingga serat seperti hemiselulosa, selulosa dan lignin dapat diuraikan menjadi senyawa-senyawa yang lebih sederhana.

Hasil penelitian menunjukkan ada perbedaan sangat nyata $(\mathrm{P}<0,01)$ antara kontrol dan perlakuan Alkali kapur $\mathrm{Ca}(\mathrm{OH})_{2}$ dan Fermentasi Aspergillus niger. Pada kontrol nilai kandungan selulosa sebesar 50,63\% ${ }^{\mathrm{e}}$, sedangkan pada kombinasi Alkali kapur $\mathrm{Ca}(\mathrm{OH})_{2}$ dan Fermentasi Aspergillus niger kandungan Selulosa terendah pada perlakuan A5F5 sebesar $36,99 \%$ dan yang tertinggi pada perlakuan A4F3 sebesar 46,28\% ${ }^{\mathrm{d}}$. Berdasarkan data interaksi, kombinasi A5F5= (5\% kapur $+4 \mathrm{ml}$ Aspergillus niger $)$ adalah kombinasi yang paling baik. Hal ini disebabkan karena adanya interaksi antara proses alkalinasi dan fermentasi. Proses alkalinasi berfungsi merenggangkan ikatan Selulosa dan proses fermentasi berperan menurunkan nilai kandungan selulosa. Hal ini sesuai pendapat Gunam et al. (2004) dan Lee et al. (2009) semakin tinggi konsentarsi larutan alkali $\mathrm{NaOH}$, semakin besar juga kemampuan untuk melarutkan lignin dan merusak struktur selulosa akan semakin bertambah, yang mengakibatkan serat-serat selulosa akan semakin longgar sehingga semakin mudah dihidrolisis oleh mikroorganisme baik untuk pertumbuhannya maupun untuk produksi enzim selulase. Hasil analisa data interaksi pengaruh penambahan kapur $\mathrm{Ca}(\mathrm{OH})_{2}$ dan dosis inokulum terhadap kandungan Selulosa. menunjukkan interaksi positif, hal ini dapat dilihat pada Gambar 3.

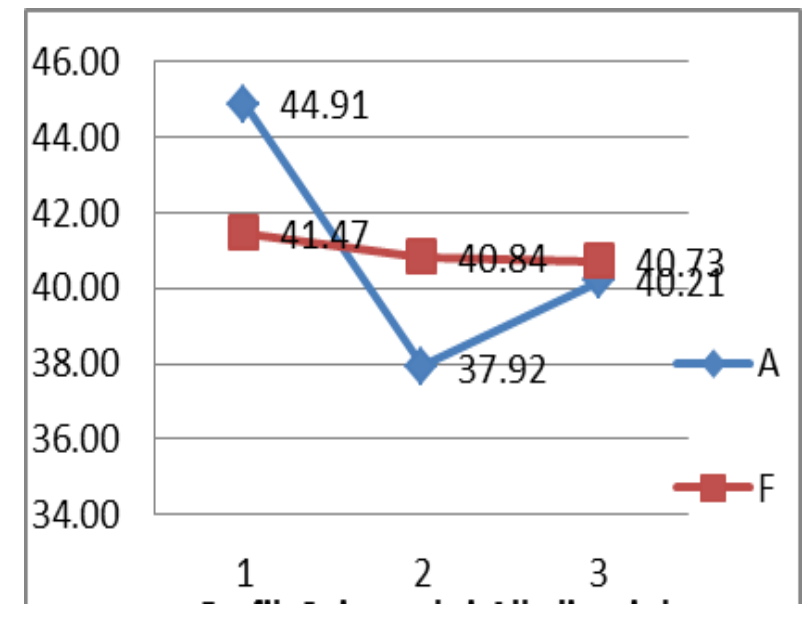

Gambar 3. Interaksi penambahan kapur dan fermentasi terhadap selulosa

Dalam kondisi substrat yang tidak basa tidak mempengaruhi inokulum Aspergillus niger pada proses fermentasi, sehingga inokulum dapat berkembang dengan baik dan menghasilkan enzim selulase yang berfungsi untuk mecah dan merombak ikatan selulosa selama inkubasi sehingga kandungan Selulosa dapat menurun. Hal ini sesuai pendapat Soares (2017) enzim selulase yang dihasilkan dari inokulum Aspergillus niger mampu merombak ikatan-ikatan kompleks dari serat menjadi komponen yang lebih sederhana. 


\section{KESIMPULAN DAN SARAN}

Kesimpulan penelitian ini adalah (1) Jerami jagung yang diproses dengan alkalinasi dan fermentasi dapat menurunkan kandungan NDF, ADF dan Selulosa, dan (2). Perlakuan terbaik pada kombinasi alkalinasi kapur 5\% dan dosis $5 \mathrm{ml}$ inokulum dengan kandungan NDF 47,58\%, ADF 43,39\% dan selulosa 36,99\%. Selanjutnya disarankan perlu penelitian lanjutan mengenai kombinasi larutan kapur 5\% dan dosis Aspergillus niger yang ditingkatkan untuk mengetahui hasil yang lebih optimal dan aplikasi sebagai pakan ternak ruminansia.

\section{DAFTAR PUSTAKA}

Banwart. 1989. Basic food microbiology. 2nd ed. New York (USA): AVI, Van Nostrand, Reinnold.

Fadel EMA, Sekine J, Hishinuma M, Hamana K. 2003. Effects of ammonia, urea plus calcium hydroxide and animal urine treatments on chemical composition and in sacco degradability of rice straw. Asian-Aust J Anim Sci. 16:368-373.

Firdos T, Khan AD, Shah FH. 1989. Improvement in the digestibility of bagasse pith by chemical treatment. J Islamic Academy Sci. 2:89-92.

Gunam IBW, Hardiman, Utami T, 2004. Chemical pre-treatments on bagasse to enhance hydrolysis of its cellulose enzymatically. The 3th Hokkaido Indonesian Student Association Scientific Meeting (HISAS 3). Sapporo (Japan).

Jalaluddin, Rizal S. 2005. Pembuatan pulp dari jerami padi menggunakan natrium hidroksida. J Sistem Teknik Industri. 6:53-56.

Larasati TRD, Mulyana N, Anggriawan M, Effendi. 2015. Produksi enzim selulase oleh fungi selulotik yang diradiasi sinar gamma dalam fermentasi jerami padi. Jakarta (Indonesia): Fakultas Sains dan Teknologi Program Studi Biologi (Bioteknologi). Universitas Al Azhar Indonesia.

Lee SH, Doherty TV, Linhardt RJ, Dordick JS. 2009. Ionic liquid-mediated selective extraction of lignin from wood leading to enhanced enzymatic cellulose hydrolysis. Biotechnol Bioeng. 102:1368-1376.

Ni'mah F, Argo DB, Lutfi M, Maharani DM, Putranto AW. 2014. Perbandingan proses pretreatment degradasi lignin jerami padi dengan wet milling dan dry milling pada produksi bioetanol. J Teknologi Pertanian. 15:77-84.

Raharjo YC, Haryati T, Gultom D. 2000. Evaluasi nilai nutrisi pollard gandum terfermentasi dengan Aspergillus niger Nrrl 337 pada itik alabio dan mojosari. Bogor (Indonesia): Balai Penelitian Ternak.

Shabi Z, Arieli A, Bruckental I, Aharoni A, Zamwel S, Bor A, Tagari H. 1998. Effect of the syncronization of the degradation of dietary crude protein and organic matter and feeding frequency on ruminal fermentation and flow of digesta in the abomasum of dairy cows. J Dairy Sci. 81:1991-2000.

Soares D, Irfan HD, Muhammad HN. 2017. Pengaruh jenis inokulum Aspergillus niger dan Saccharomyces cereviseae terhadap komposisi nutrisi ampas putak. J Ilmu-ilmu Peternakan. 28:90-95. 